\title{
IGF-1 as a Drug for Preterm Infants: A Step-Wise Clinical Development
}

\section{Citation}

Hellström, Ann, David Ley, Boubou Hallberg, Chatarina Löfqvist, Ingrid HansenPupp, Luca A. Ramenghi, Jan Borg, Lois E. H. Smith, and Anna-Lena Hård. 2017. "IGF-1 as a Drug for Preterm Infants: A Step-Wise Clinical Development." Current Pharmaceutical Design 23 (38): 5964-5970. doi:10.2174/1381612823666171002114545. http:// dx.doi.org/10.2174/1381612823666171002114545.

\section{Published Version}

doi:10.2174/1381612823666171002114545

\section{Permanent link}

http://nrs.harvard.edu/urn-3:HUL.InstRepos:35981903

\section{Terms of Use}

This article was downloaded from Harvard University's DASH repository, and is made available under the terms and conditions applicable to Other Posted Material, as set forth at http:// nrs.harvard.edu/urn-3:HUL.InstRepos:dash.current.terms-of-use\#LAA

\section{Share Your Story}

The Harvard community has made this article openly available.

Please share how this access benefits you. Submit a story.

Accessibility 


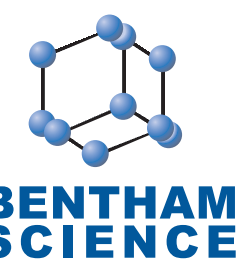

\section{IGF-1 as a Drug for Preterm Infants: A Step-Wise Clinical Development}

Ann Hellström ${ }^{1} *$, David Ley ${ }^{2}$, Boubou Hallberg ${ }^{3}$, Chatarina Löfqvist $^{1}$, Ingrid Hansen-Pupp ${ }^{2}$, Luca A. Ramenghi ${ }^{4}$, Jan Borg ${ }^{5}$, Lois E. H. Smith ${ }^{6}$ and Anna-Lena Hård ${ }^{1}$

${ }^{I}$ Department of Ophthalmology, Institute of Neuroscience and Physiology, Sahlgrenska Academy, University of Gothenburg, Gothenburg, Sweden; ${ }^{2}$ Department of Pediatrics, Institute of Clinical Sciences Lund, Lund University and Skane University Hospital, Lund, Sweden; ${ }^{3}$ Department of Neonatology, Karolinska Institute and University Hospital, Stockholm, Sweden; ${ }^{4}$ Genova Neonatal Intensive Care Unit, Instituto Pediatrico Giannina Gaslini, Genova Italy; ${ }^{5}$ Former Premacure AB, Uppsala, Sweden; ${ }^{6}$ Department of Ophthalmology, Boston Children's Hospital, Harvard Medical School, Boston, MA

\section{A R T I C L E H I S T O R Y}

Received: August 1, 2017 Accepted: September 28, 2017

DOI:

$10.2174 / 1381612823666171002114545$

Abstract: Background: Insulin-like growth factor 1 (IGF-1) is a mitogenic hormone involved in many processes such as growth, metabolism, angiogenesis and differentiation. After very preterm birth, energy demands increase while maternal supplies of nutrients and other factors are lost and the infant may become dependent on parenteral nutrition for weeks. Low postnatal IGF-1 concentrations in preterm infants are associated with poor weight gain, retinopathy of prematurity (ROP) and other morbidities. We will describe the process by which we aim to develop supplementation with recombinant human (rh) IGF-1 and its binding protein rhIGFBP-3 as a possible therapy to promote growth and maturation and reduce morbidities in extremely preterm infants.

Methods: In order to calculate a dose of IGF-1 tolerated by neonates, a pharmacokinetic study of transfusion with fresh frozen plasma was performed, which provided a relatively low dose of IGF-1, (on average $1.4 \mu \mathrm{g} / \mathrm{kg}$ ), that increased serum IGF-1 to levels close to those observed in fetuses and preterm infants of similar GAs. Thereafter, a Phase I 3 hours IV infusion of rhIGF-1/rhIGFBP-3 was conducted in 5 infants, followed by a Phase II study with four sections (A-D). In the Phase II, sections A-D studies, time on infusion increased and younger gestational ages were included.

Results: IV infusion increased IGF-1 but with short half-life $(0.5 \mathrm{~h})$ implying a need for continuous infusion. In order to obtain in utero levels of IGF-I, the dose was increased from 100 to $250 \mu \mathrm{g} / \mathrm{kg} / 24 \mathrm{~h}$ and the infusion was prolonged from 3 weeks postnatal age until a postmenstrual age of 29 weeks and 6 days.

Conclusion: The purpose has been to ensure high-quality research into the development of a new drug for preterm infants. We hope that our work will help to establish a new standard for the testing of medications for preterm infants.

Keywords: Preterm infant, IGF-1, pharmacokinetic, drug development, preterm morbidity.

\section{INTRODUCTION}

Insulin-like growth factor 1 (IGF-1) is a mitogenic hormone involved in many processes such as growth, metabolism, angiogenesis and differentiation. After very preterm birth, energy demands increase while maternal supplies of nutrients and other factors are lost and the infant may become dependent on parenteral nutrition for weeks. Impaired transition to extrauterine life with under-nutrition, infections and insufficient lung maturation results in a catabolic state with very low serum IGF-1 concentrations compared to in utero (Fig. 1).

IGF-1 plays a crucial role in fetal development and IGF-1 rather than growth hormone $(\mathrm{GH})$ is the main driver of fetal growth [1]. IGF-1 influences brain cell proliferation, apoptosis, myelination, neurogenesis, maturation and differentiation [2]. Most other organs including the vasculature also depend on IGF-1 for proper growth and differentiation [3]. In addition, IGF-1 has insulin-like effects and is involved in glucose and lipid metabolism [4]. Low postnatal IGF-1 concentrations in preterm infants are associated with poor weight gain, retinopathy of prematurity (ROP) and other morbidities [5]. In animals on hypocaloric nutrition, experimental studies on IGF-1 supplementation have shown decreased weight loss and

\footnotetext{
*Address correspondence to this author at the Department of Ophthalmology, Institute of Neuroscience and Physiology, Sahlgrenska Academy, University of Gothenburg, Gothenburg, Sweden;

E-mail: ann.hellstrom@medfak.gu.se
}

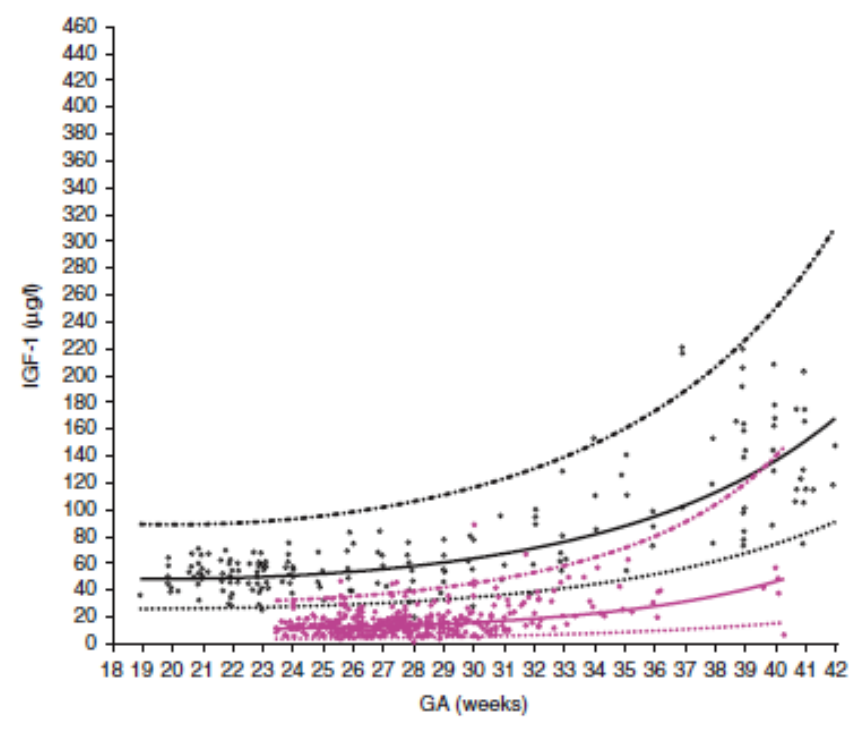

Fig. (1). Intrauterine and preterm infant serum IGF-1 levels. Open black circles represent IGF-1 in normal in utero fetuses. Closed pink circles represent IGF-1 in preterm infants. Solid black line represents mean predicted physiological levels of corresponding intrauterine levels $(n=174)$. Solid pink line represents mean predictive values of preterm infants $(n=137)$. Dashed black line represents upper prediction interval $\left(95^{\text {th }}\right)$. From Hellström et al. 
[3] Insulin-like growth factor 1 has multisystem effects on foetal and preterm infant development. Copyright (C)2016 Acta Pediatrica, reproduced with permission. (The color version of the figure is available in the electronic copy of the article).

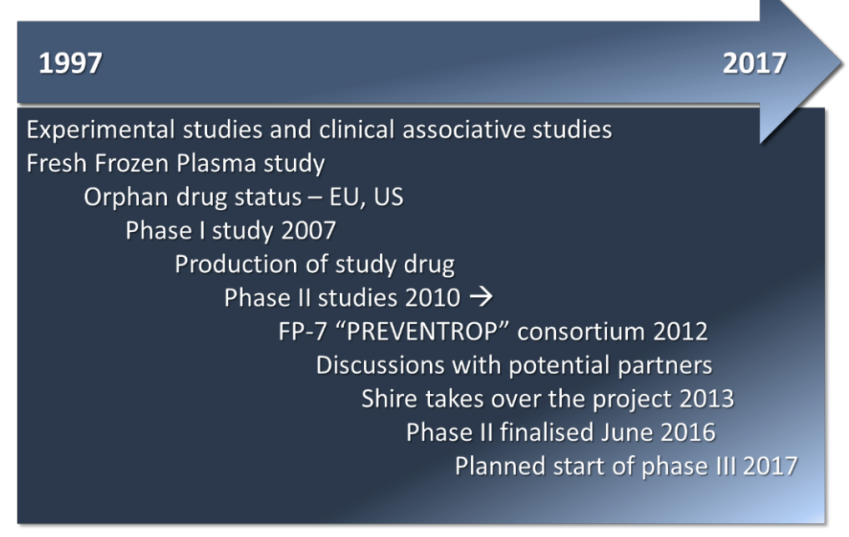

Fig. (2). Timeline of drug development in a neonatal clinical setting.

improved protein anabolism [6] and a reduction in oxygen induced retinopathy (OIR) [7]. We hypothesized that treating extremely preterm infants with IGF-1 to obtain serum concentrations within the normal intrauterine range would improve growth and reduce ROP and other neonatal morbidities. After a description of IGF-1 and its role during the third trimester, we will describe the process by which we aim to develop supplementation with recombinant human (rh) IGF-1 and its binding protein rhIGFBP-3 as a possible therapy to promote growth and maturation and reduce morbidities in extremely preterm infants; a timeline of this drug development is seen in Fig. 2.

\section{IGF-1 IN FETAL DEVELOPMENT}

Most circulating IGF-1 is secreted by the liver but IGF-1 is secreted by almost all fetal tissues at some developmental stage and exerts its actions in endocrine, paracrine and autocrine manners by binding to the IGF-1 receptor [8]. The roles of locally secreted versus circulating IGF-1 is poorly understood but the latter is thought to signal the nutritional state of the body [9]. At least six binding proteins (BP) control IGF-1 actions. IGFBP-3 is the main binding protein in the circulation that binds IGF-1 together with an acid labile subunit (ALS) to form a ternary complex, which prolongs the half-life of circulatory IGF-1. After intravenous (IV) infusion of rhIGF-1 in healthy men, the half -life of free IGF-1 was estimated to range between $\sim 14 \mathrm{~min}$ [10] and $0.34-0.59 \mathrm{~h}$ [11] while the halflife for total IGF-1 was $\sim 17 \mathrm{~h}$. [11]. In addition to being a carrier protein, IGFBP-3 also has IGF-1 independent functions and promotes vascular regrowth in oxygen induced retinopathy [12]. IGFBP-1 reduces the availability of free IGF-1 and is negatively regulated by insulin.

During gestation circulating fetal IGF-1 is regulated by the nutrient supply from the mother and increases during the third trimester. Amniotic fluid contains IGF-1 and is swallowed by the fetus [13]. Cord serum IGF-1 concentrations are correlated with fetal size and fat mass[14].

During the third trimester, massive growth and differentiation take place to prepare the infant for extrauterine life. After extremely preterm birth, longitudinal growth slows down and postnatal complications such as intraventricular hemorrhage (IVH), ROP, bronchopulmonary dysplasia (BPD), necrotizing enterocolitis (NEC), hyperglycemia and sepsis are common. Persistent low neonatal serum IGF-1 in very preterm infants is associated with reduced weight gain [15] and impaired brain growth and development [16] and with ROP and other morbidity [5], as well as poorer neurode- velopment at 2 years of age [17]. A more comprehensive description of IGF-1 in fetal life and in the neonatal period of extremely preterm infants is provided in the previous reviews [3, 18-20].

\section{THE STUDY DRUG}

Mecasermin rinfabate, a complex of recombinant human Insulin-like Growth Factor-1 and recombinant human Insulin-like Growth Factor Binding Protein-3 (rhIGF-1/rhGFBP-3) was developed to increase the half-life of rhIGF-1 in the circulation and to reduce side effects, especially hypoglycemia, seen with rhIGF-1 without the combination with rhGFBP-3.

rhIGF-1 and rhIGFBP-3 are produced by two separate E. coli strains: one containing the human gene for insulin-like growth factor-1 (IGF-1), the other containing the human gene for insulin-like growth factor-binding protein-3 (IGFBP-3). The rhIGF-1 and rhIGFBP-3 proteins are complexed in a 1:1 molar ratio for the formation of mecasermin rinfabate with a molecular weight of 36,381 daltons. The binary complex of IGF-1/IGFBP-3 further combines with a third circulating protein, the GH-dependent acid-labile subunit (ALS), to form a ternary complex of $\sim 140-150 \mathrm{kD}$ which represents the natural physiologic reservoir of IGF-I.

In 2005, rhIGF-1/rhIGFBP-3 (IPLEX ${ }^{\mathrm{TM}}$, Insmed Therapeutic Proteins (ITP), Boulder, CO, USA) was approved by the FDA for the treatment of severe primary IGF-1 deficiency due to growth hormone insensitivity syndrome but was later withdrawn from the market due to patent litigation. Studies have also been performed in patients with diabetes type 1 and 2, severe insulin resistance, Donohue syndrome [21] and severe burns. A comprehensive review of these studies is provided by Williams et al. [22]. In addition, patients with myotonic dystrophy type 1 have been treated with rhIGF-1/IGFBP-3[23].

IPLEX $^{\mathrm{TM}}$ was initially provided as a $60 \mathrm{mg} / \mathrm{mL}$ solution for once daily subcutaneous injection in doses of 0.5 to $2.0 \mathrm{mg} / \mathrm{kg}$. However, due to deficient subcutaneous tissue in preterm neonates and to provide better control of circulating levels of IGF-1 it was decided to use the intravenous route in the clinical development program. Based on results from the frozen plasma study it was decided to use a starting dose of $5 \mu \mathrm{g} / \mathrm{kg} /$ during 3 hours in the first patient in the phase I trial.

In the phase I study, drug product mecasermin rinfabate $\left(\right.$ IPLEX $\left.^{\mathrm{TM}}\right)$ at a concentration of $60 \mathrm{mg} / \mathrm{mL}$ was diluted with $10 \%$ glucose in two steps at the hospital pharmacy to provide suitable individualized concentrations for $3 \mathrm{~h}$ infusions. In the phase II study (sections A and B), a more diluted form of drug product was manufactured from IPLEX ${ }^{\mathrm{TM}}$ drug substance by a 1,200 times dilution from $60 \mathrm{mg} / \mathrm{mL}$ to $50 \mu \mathrm{g} / \mathrm{mL}$ (Premiplex ${ }^{\mathrm{TM}}$, Unitech Pharma, Matfors, subsequently replaced by Rechon Life Sciences, Limhamn, both in Sweden).

\section{A PHARMACOKINETIC STUDY OF FRESH FROZEN PLASMA}

Fresh frozen adult plasma contains varying amounts of IGF-1 and IGFBP-3 and is used for volume expansion and as a source of coagulation factors in preterm infants. In preparation for possible future supplementation studies, the effects of fresh frozen plasma administration on serum IGF-1 and IGFBP-3 were studied [24]. Twenty extremely preterm infants with gestational age $(\mathrm{GA})<28$ weeks at birth, who required transfusions of fresh frozen plasma for clinical reasons during the first week of life were enrolled from December 2005 to July 2006. A sample from each batch of plasma was obtained immediately before initiation of transfusion. Sampling of neonatal blood was performed immediately before and directly after transfusion and at 6,12, 24 and $48 \mathrm{~h}$ after completed transfusion. Infant plasma glucose concentrations were analyzed before, immediately after and at $6 \mathrm{~h}$ after completed transfusion. The mean (SD) volume of administered plasma was $11 \mathrm{ml} / \mathrm{kg}$ (3.1) during a median of $120 \mathrm{~min}$ (range 90-240) at a median age of $2 \mathrm{~d}$ (range 1- 
7). The mean (SD) total administered amount of IGF-1 and IGFBP3 was $1.4(0.5)$ and $31 \mu \mathrm{g} / \mathrm{kg}(11.5)$ respectively.

Immediately after completion of administration mean (SD) serum IGF-1 concentration increased by $133 \%$ from $11(6.4)$ to 25 $\mu \mathrm{g} / 1(9.3)(\mathrm{p}<0.001)$ and IGFBP-3 by $61 \%$ from $815(451)$ to 1311 $(508) \mu \mathrm{g} / \mathrm{l}$. The concentrations of both proteins remained higher at 6 and $12 \mathrm{~h}$ after completed transfusion but not thereafter (Fig. 3).
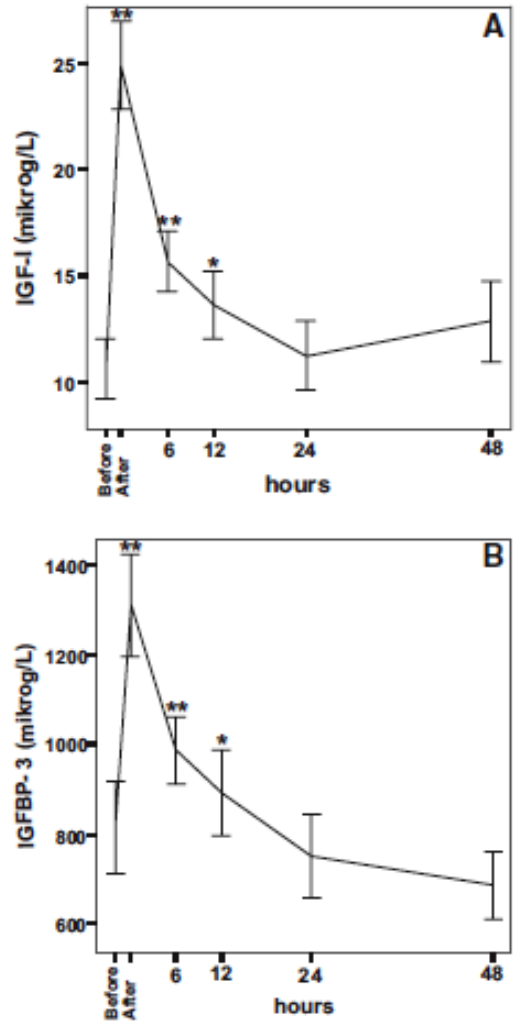

Fig. (3). Mean concentrations of IGF-I (A) and IGFBP-3 (B) before $(\mathrm{n}=20)$ and at $6(n=19), 12(n=19), 24(n=16)$ and $48 h(n=14)$ after FFP. Error bars show \pm 1 SEM. *, $\mathrm{P}<0.05$ and $* *, \mathrm{P}<0.01$ denote significant differences compared with levels before transfusion of FFP. Copyright (CJCEM, reproduced with permission.
The half-life of IGF-1 in the circulation of neonates of $0.5,1.0$ and $1.5 \mathrm{~kg}$ was estimated to be approximately $2.9,3.4$ and $3.8 \mathrm{~h}$ respectively. An estimation of the amount of IGF-1 retained in the circulation after transfusion also indicated that the elimination rate increased with decreasing GA at birth. In addition, lower birth weight (BW) was associated with shorter serum IGF-1 half-life.

Infant plasma glucose concentrations were not affected by the fresh frozen plasma transfusions.

Thus, transfusion with fresh frozen plasma providing a relatively low dose of IGF-1, (on average $1.4 \mu \mathrm{g} / \mathrm{kg}$ ), was shown to increase serum IGF-1 to levels close to those observed in fetuses and preterm infants of similar GAs (25-27). It was calculated that an IV dose between 1 and $2 \mu \mathrm{g} / \mathrm{kg}$ of IGF-1 would be required to achieve serum concentrations in the range of those of a fetus of similar postmenstrual age (PMA). This pharmacokinetic information was the basis for the start of the below described stepwise clinical phase I-II development (Fig. 4).

\section{PHASE I STUDY: THREE-HOUR INFUSION OF rhIGF- 1/rhIGFBP-3}

\subsection{Patients and Methods}

Based on the results of the fresh frozen plasma study a pharmacokinetic and dosing study [28] of rhIGF-1/IGFBP-3 infusion for three hours was performed (January -November 2007) in 5 infants (3 females) with mean GA $27 \mathrm{wk}$ and mean BW of $1022 \mathrm{~g}$. For inclusion, serum IGF-1 concentration at postnatal day 2 had to be $<25 \mu \mathrm{g} / 1$ and plasma glucose level $2.5-10 \mathrm{mmol} / \mathrm{l}$. The study drug was mecasermin rinfabate (IPLEX ${ }^{\mathrm{TM}}$ ) and the dose in the first study subject of rhIGF-1/rhIGFBP-3 was $5 \mu \mathrm{g} / \mathrm{kg} / 3 \mathrm{~h}$ corresponding to $1.1 \mu \mathrm{g} / \mathrm{kg} / 3 \mathrm{~h}$ of rhIGF-1. The calculated dose was infused intravenously on postnatal day 3 over $3 \mathrm{~h}$ through an umbilical venous catheter.

Blood samples were drawn from a peripheral arterial line to determine serum IGF-1 and IGFBP-3 immediately before $(-3 \mathrm{~h})$ and after completion of infusion $(0 \mathrm{~h})$ and at $1,2,6,12,18,24,48 \mathrm{~h}$ and 14 days after infusion. Vital signs and infant's health status were monitored throughout the study. Blood glucose concentrations were measured immediately before and after infusion and at 1, 12, 24, 48 $\mathrm{h}$ after infusion. Serum insulin was measured before $(-3 \mathrm{~h})$ and at 1 and $24 \mathrm{~h}$ after infusion. Serum potassium $(\mathrm{K})$ and sodium $(\mathrm{Na})$ were measured at $0,1,2,3,4,5 \mathrm{~h}$ and 14 days after infusion. Heart rate and blood pressure were measured before and immediately after

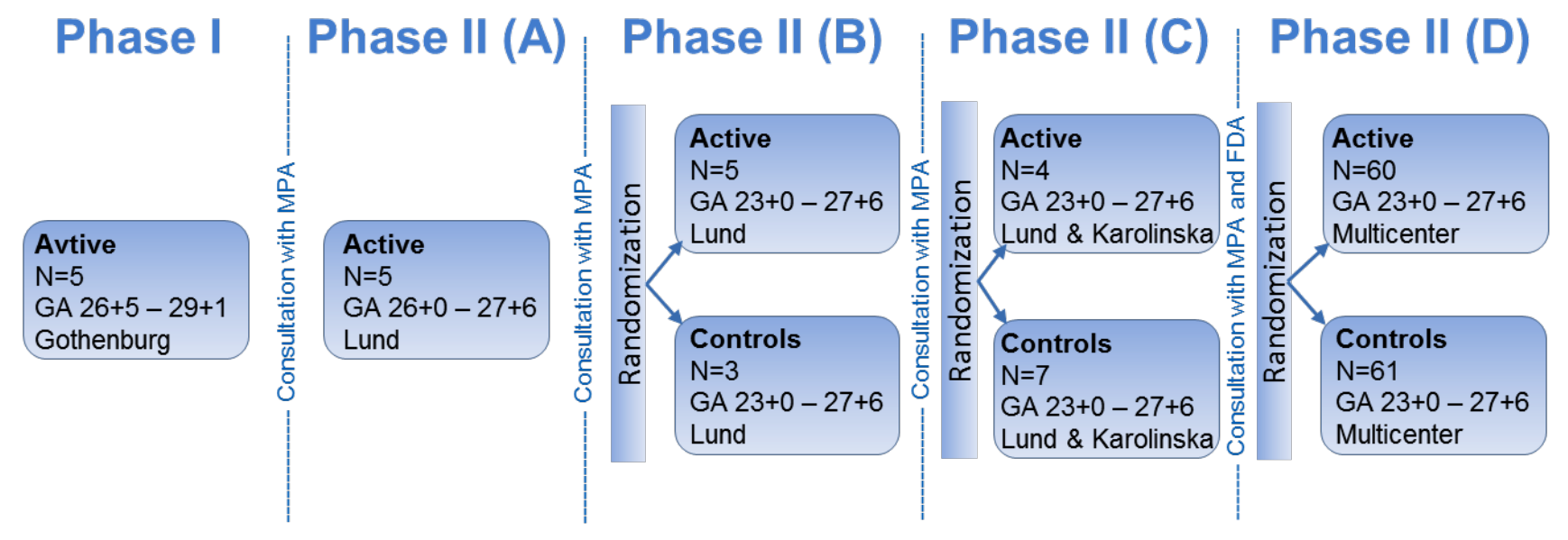

Fig. (4). Illustration of step-wise clinical phase I-II development of IGF-I as a drug for preterm infants. 
infusion and then once an hour up to $12 \mathrm{~h}$. Body weight was measured daily from birth to study day eight.

\subsection{Results}

The infants received a dose of between (min-max) $6-59 \mu \mathrm{g} / \mathrm{kg} / 3$ $\mathrm{h}$ of rhIGF-1/rhIGFBP-3. Median (range) serum concentration of IGF-1 before and after infusion was 18 [12-28] and 38 (25-59) $\mathrm{ng} / \mathrm{mL}$ and of IGFBP-3 771 (651-1047) and 838 (658-1182) $\mathrm{ng} / \mathrm{mL}$. In all five infants, serum IGF-1 levels immediately after infusion were in the "physiologic range" defined as the normal intrauterine range at corresponding GA $(20-60 \mu \mathrm{g} / \mathrm{l})$ [26]. However, the half-life of IGF-1 in the circulation was shorter than expected. The calculated typical half-lives of total IGF-1 in infants of $0.5 \mathrm{~kg}-1.5 \mathrm{~kg}$ were $0.72-0.95 \mathrm{~h}$ and of IGFBP-3; $0.76-1.0 \mathrm{~h}$ (Fig. 5).

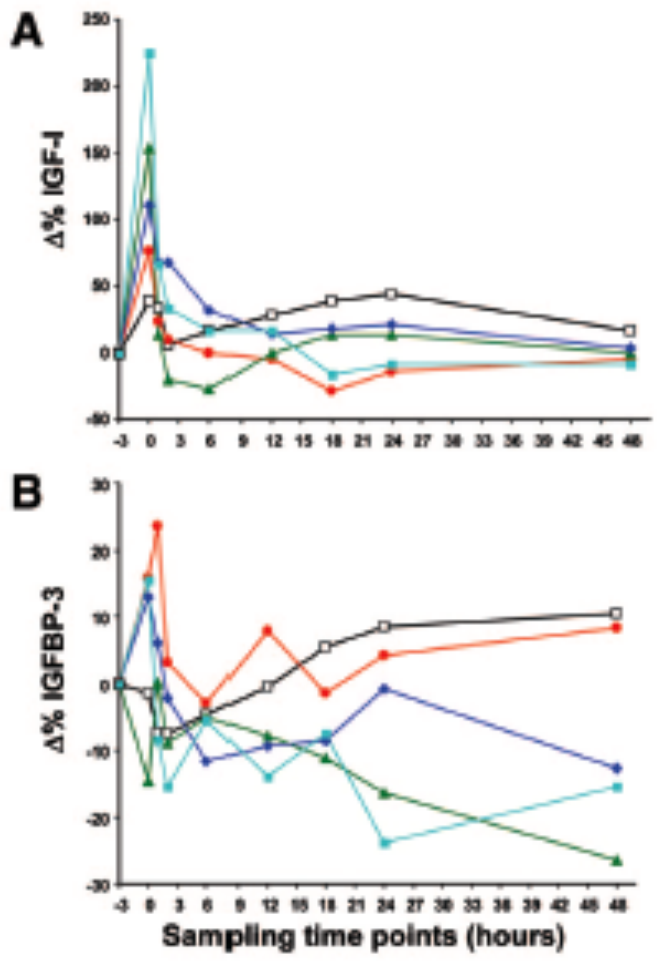

Fig. (5). A. $\Delta \%$ IGF-I from baseline after $3 \mathrm{~h}$ infusion of IGF-I/IGFBP-3 in different doses $(\mathrm{n}=5)$ in five study subjects. Sampling time points are immediately before study drug infusion (-3), immediately following completed infusion of drug (0), and at 1,2, 6, 12, 18, 24 and 48 hours post completed drug infusion. Number 1 (BW 880g; $6 \mu \mathrm{g} / \mathrm{kg}$ ): unfilled boxes and black line, 2 (BW $1220 \mathrm{~g} ; 24 \mu \mathrm{g} / \mathrm{kg}$ ): red filled circle and red line, 3 (BW 760g; 33 $\mu \mathrm{g} / \mathrm{kg}$ ): green filled triangles and green line, 4 (BW $1115 \mathrm{~g} ; 33 \mu \mathrm{g} / \mathrm{kg}$ ): dark blue rhomb and dark blue line, 5 (BW $810 \mathrm{~g} ; 59 \mu \mathrm{g} / \mathrm{kg}$ ): light blue filled boxes and light blue line.

B. $\Delta \%$ IGFBP-3 from baseline after $3 \mathrm{~h}$ infusion of IGF-I/IGFBP-3 in different doses $(\mathrm{n}=5)$ in five study subjects. Sampling time points are immediately before study drug infusion (-3), immediately following completed infusion of drug (0), and at 1, 2, 6, 12, 18, 24 and 48 hours post completed drug infusion. One $(880 \mathrm{~g} ; 6 \mu \mathrm{g} / \mathrm{kg})$ : unfilled boxes and black line, $2(1220 \mathrm{~g} ; 24$ $\mu \mathrm{g} / \mathrm{kg})$ : red filled circle and red line, $3(760 \mathrm{~g} ; 33 \mu \mathrm{g} / \mathrm{kg})$ : green filled triangles and green line, $4(1115 \mathrm{~g} ; 33 \mu \mathrm{g} / \mathrm{kg})$ : dark blue rhomb and dark blue line, \#5 (810g; $59 \mu \mathrm{g} / \mathrm{kg})$ : light blue filled boxes and light blue line. Copyright $($ Pediatric Research, reproduced with permission. (The color version of the figure is available in the electronic copy of the article).

All safety variables were within the normal range. Thus, an IV infusion of an equimolar preparation of rhIGF-1/rhIGFBP-3 could increase serum IGF-1 concentrations in very preterm infants to those found in fetuses of similar PMA, but the half-life was less than an hour and shorter than after fresh frozen plasma infusion $(\sim 3 \mathrm{~h})$. In the plasma study we found decreasing half-life of IGF-1 with decreasing BW and GA at birth [24] which might be attributed to lack of ALS. In cord serum of a neonate at 27 weeks of gestation, ALS was not detectable and no ternary complex formation was found [29]. In adolescents with growth hormone insensitivity syndrome who were treated with a daily subcutaneous injection of rhIGF-1/rhIGFBP-3 $(0.5 \mathrm{mg} / \mathrm{kg})$ the IGF-1 half-life was $21+4$ hours [30].

The short half-lives of both IGF-1 and IGFBP-3 in very preterm infants after IV infusion of rhIGF-1/rhIGFBP-3 indicate that it should be administered as a continuous IV infusion to maintain the targeted serum IGF-1 concentration. Pharmacokinetic modeling suggested that $100-150 \mu \mathrm{g} / 24 \mathrm{~h}$ of $\mathrm{rhIGF}-1 / \mathrm{rhIGFBP}-3$ corresponding to $21-32 \mu \mathrm{g}$ of IGF- 1 is needed to increase IGF-1 concentrations into the lower intrauterine range of an infant weighing $1000 \mathrm{~g}$ at birth.

In discussions with The Swedish Medical Product Agency (MPA) it was decided that the achieved results merited for a phase II trial in which the results from the phase I study together with those from the fresh frozen plasma study should serve as basis for dosing and administration.

\section{PHASE II SECTION A STUDY: LONGITUDINAL INFU- SION OF rhIGF-1/rhIGFBP-3 DURING THE FIRST WEEK OF LIFE}

\subsection{Patients and Methods}

In the next study [31] (June 2010-June 2011) five infants with a median GA of $26 \mathrm{w}+6 \mathrm{~d}$ and median BW of $900 \mathrm{~g}$ received IV continuous infusion of Premiplex ${ }^{\mathrm{TM}}$ (Premacure AB Uppsala, Sweden), diluted in $10 \%$ glucose from $50 \mu \mathrm{g} / \mathrm{mL}$ to personalized concentrations and administered at individualized infusion rates for a median (range) duration of 168 (47-168) h. The initial Premiplex dose was determined based on the infant's PMA, fetal IGF-1 serum concentration for corresponding GA and current infant weight. Dose adjustments were carried out based on the measured serum IGF-1 level at $4 \mathrm{~h}$ after the start of each new infusion.

Serum IGF-1 target range corresponding to the lower range of previously published intrauterine levels for corresponding GA [28] was set to $20-40 \mu \mathrm{g} / 1$. Infusion of Premiplex was started a median (range) postnatal age of 19.0 (9.8-27.5) hours. Blood samples for determination of serum IGF-1 and IGFBP-3 were drawn immediately before start and at 2, 4, 6, and $12 \mathrm{~h}$ after completion of infusion. After change of infusion solutions, samples were taken every $24 \mathrm{~h}$ as well as $4 \mathrm{~h}$ after change of Premiplex dose. Samples were also obtained immediately before the start of the last infusion and at $0.5,2,24$, and $72 \mathrm{~h}$ after the completion and thereafter once weekly up to $40 \mathrm{w}$ PMA. Thorough examinations following glucose homeostasis, retinal vascular development, kidney development, and general as well as brain growth were undertaken.

\subsection{Results}

The administered doses of Premiplex ranged from 21 to 111 $\mu \mathrm{g} / \mathrm{kg} / 24 \mathrm{~h}$. The concentrations of IGF-1 and IGFBP-3 increased significantly during infusion with Premiplex $(p<0.001)$ to the lower end of the normal intrauterine range. The developed pharmacokinetic model predicted that a dose of the rhIGF-1/rhIGFBP-3 complex of between 75 and $100 \mu \mathrm{g} / \mathrm{d}$ would be required to establish serum IGF-1 concentrations within the intrauterine range in a $1000 \mathrm{~g}$ infant. That dose is somewhat lower than that calculated in the previous study $(100-150 \mu \mathrm{g} / \mathrm{d})$ [28].

No evident adverse effects were seen and the results raised no concerns from the members of the safety committee.

Serum IGF-1 levels fell below intrauterine concentrations after completion of 7 days of infusion indicating the need for more pro- 

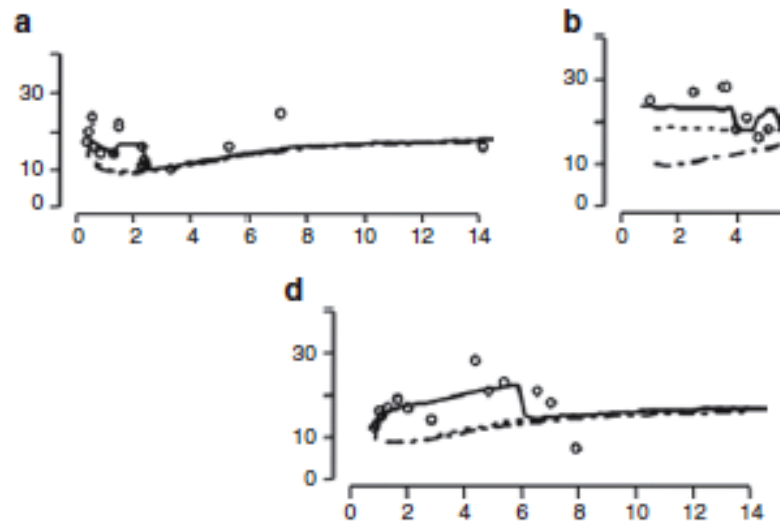
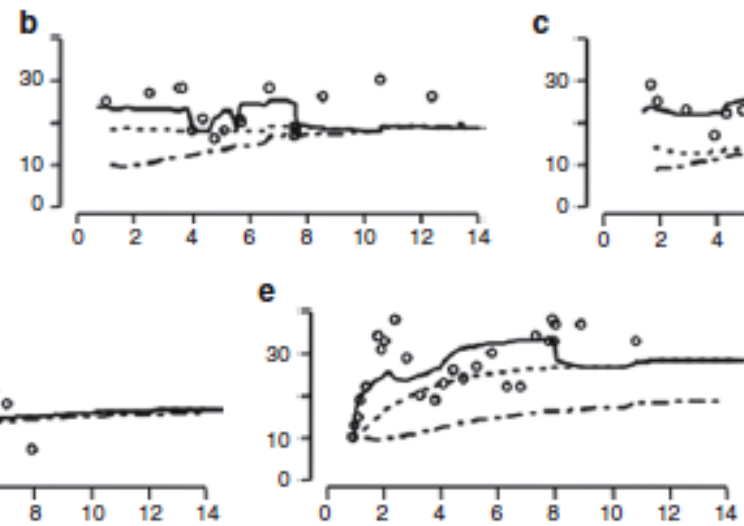

Fig. (6). Observed and model-predicted serum IGF-I concentrations, in relation to postnatal age, in five very preterm children, chronological age (days) on the $\mathrm{X}$-axis and serum IGF-I levels $(\mu \mathrm{g} / \mathrm{L}$ ) on the $\mathrm{y}$-axis. (a) patient 1; (b) patient 2; (c) patient 3; (d) patient 4; (e); patient 5. All the infants received continuous intravenous infusions of rhIGF-I/rhIGFBP-3. Population predicted endogenous concentrations are shown for an untreated typical child with the same body weight as that of the treated subject. The individual predictions consider unexplained inter-individual differences. The individual total predictions show the best model to fit the observed data and the administered doses of rhIGF-I/rhIGFBP-3. The observed values are depicted as circles, the individual predicted endogenous serum IGF-I concentrations as a dotted line, the population predicted endogenous serum IGF-I concentrations as a broken line and the individual predicted total serum IGF-I as a solid line. Copyright $C$ Pediatric Research, reproduced with permission.

longed administration which was designed for in sections B-C (Fig. 6).

\section{PHASE II SECTION B AND C STUDIES: CONTINUOUS LONGITUDINAL INFUSION OF rhIGF-1/rhIGFBP-3 IN EXTREMELY PRETERM INFANTS: EVALUATION OF FEASIBILITY IN A PHASE II STUDY (MANUSCRIPT SUBMITTED)}

In Sections B and C (November 2011-July 2013), infants were randomized to receive $\mathrm{rhIGF}-1 / \mathrm{rhIGFBP}-3$ or standard care and were followed until $40 \mathrm{w}$ PMA. The main aims were to determine the dose of rhIGF-1/rhIGFBP-3 needed to reach and maintain target serum IGF-1 concentrations in a population of extremely preterm infants (GA 23 to $27 \mathrm{w}+6 \mathrm{~d}$ ) and to determine serum concentrations of IGF-1 and associated pharmacokinetic variables after continuous infusion of $\mathrm{rhIGF}-1 / \mathrm{rhIGFBP}-3$. Safety data were regularly reviewed by an independent safety committee.

\subsection{Patients and methods}

In Section B, five infants were randomized to treatment and three to standard care. In Section C, 80 infants should have been included according to the initial study protocol, but this section was halted after inclusion of 11 infants (four infants to treatment and seven infants to standard care) for optimization of dosing and serum IGF-1 target range. No safety concerns had been raised.

The study drug was administered via continuous IV infusion through a central or peripheral venous line. Infusion started within $24 \mathrm{~h}$ after birth and was continued until the infant's endogenous IGF-1 production was considered sufficient to maintain serum concentration within the target range or up to a PMA of $28 \mathrm{w}+6 \mathrm{~d}$ in Section B or $29+6$ d in Section C. Dosing of rhIGF-1/rhIGFBP-3 was individualized and a target range of $30-35 \mu \mathrm{g} / 1$ in Section B and $25-30 \mu \mathrm{g} / \mathrm{l}$ in infants with body weight $<900 \mathrm{~g}$ or $30-35$ for infants weighing $>900 \mathrm{~g}$ in Section C. The starting dose in Section B was calculated using an algorithm which included GA, basal endogenous IGF-1 concentrations and weight based on results from the phase I study [28]. In Section C, a simplified model based on BW was used with adjustments as the infant grew. Dose adjustments were performed based on the infants' actual serum IGF-1 concentrations at frequent samplings. Blood glucose was frequently assessed according to a standardized protocol and adverse effects and complications were registered.

\subsection{Results}

Eight infants were enrolled in Section B and 11 in Section C; 9 received the study drug and 10 received standard care. One treated infant in Section $\mathrm{C}$ died from cardiac tamponade, caused by chylopericardium, which was not suspected to be related to the study drug treatment.

The nine treated infants received a mean (SD) dose of 95.1 (10.6) $\mu \mathrm{g} / \mathrm{kg} /$ days for a mean (SD) duration of infusion of $14.2(6.1)$ days.

At baseline, the mean serum IGF-1 concentration in the treatment and control groups was $13.6 \mu \mathrm{g} / 1$ and $10.1 \mu \mathrm{g} / \mathrm{l}$ respectively (not a statistically significant difference) and during treatment, 22.8 $\mu \mathrm{g} / 1$ and $14.2 \mu \mathrm{g} / \mathrm{l}$ respectively. Approximately one third of treated infants did not achieve target levels and mean serum IGF-1 was only marginally above the lower bound of the range. These results prompted the discontinuation of Section $\mathrm{C}$ and further efforts to optimize dosing and re-evaluation of the target range. No adverse effects were attributed to the treatment.

\section{DEVELOPMENT OF A PHARMACOKINETIC MODEL TO OPTIMIZE rhIGF-1/rhIGFBP-3 ADMINISTRATION TO REACH TARGET IGF-1CONCENTRATIONS}

After the phase II B-C studies, the pharmaceutical company, Shire Pharmaceutical Holdings Ireland Ltd, Ireland, took over future development of the drug. In preparation for a phase II, Section D study the IGF-1 serum levels reached in Sections A-C were reviewed. The scientific basis for the chosen target range [28] was scrutinized and abandoned, since it reported IGF-1 levels from diagnostic cordocentesis due to various abnormalities which may not be representative for normal fetuses. The mean predicted serum IGF-1 level of infants born between GA 23 and 28 weeks was $13 \mu \mathrm{g} / 1\left(5^{\text {th }}-95^{\text {th }}\right.$ prediction intervals $4-40 \mu \mathrm{g} / 1$ (Fig. 1) [32]. Based on two reports of blood samples, obtained from fetuses that progressed to term birth of normal newborns $[33,34]$, mean intrauterine serum IGF-1 between GA 23 and 28 gestational weeks was estimated to be $54 \mu \mathrm{g} / 1$ with $5^{\text {th }}-95^{\text {th }}$ prediction intervals of $28-109 \mu \mathrm{g} / 1$ (Fig. 1). This was chosen as the new target range, instead of that previously used $(20-40 \mu \mathrm{g} / 1)$. 
In order to standardize the rhIGF-1/IGFBP-3 dose regimen to avoid frequent blood sampling and simplify the infusion protocol, a pharmacokinetic model was developed including data from rhIGF1/rhIGFBP-3-treated infants in the phase I and II studies $(n=19)$ and from untreated preterm infants from the phase II study Sections B/C $(n=10)$ and additional studies of untreated preterm infants $(n=137)$. Dose simulations indicated that $\geq 250 \mu \mathrm{g} / \mathrm{kg}$ administered as a continuous 24-h infusion for at least 4 weeks would increase the majority of serum IGF-1 values into the target range with less than $2 \%$ of values above this range.

Based on the model and simulation results, the recommended rhIGF-1/IGFBP-3 regimen for use in Section D was $250 \mu \mathrm{g} / \mathrm{kg} / 24 \mathrm{~h}$, as a continuous infusion up to a PMA of $29 \mathrm{w}+6 \mathrm{~d}$, with the goal to achieve serum IGF-1 concentrations of $28-109 \mu \mathrm{g} / 1$ [32].

\subsection{Verification of Model Prediction}

In the phase II Section D study performed by Shire, interim analysis of the first 10 treated and 9 control infants on standard care was performed. During the study $88.8 \%$ of individual serum IGF-1 values of treated infants were within the target range, compared to $11.1 \%$ of values of controls. No infant had values above the target range (Fig. 7)

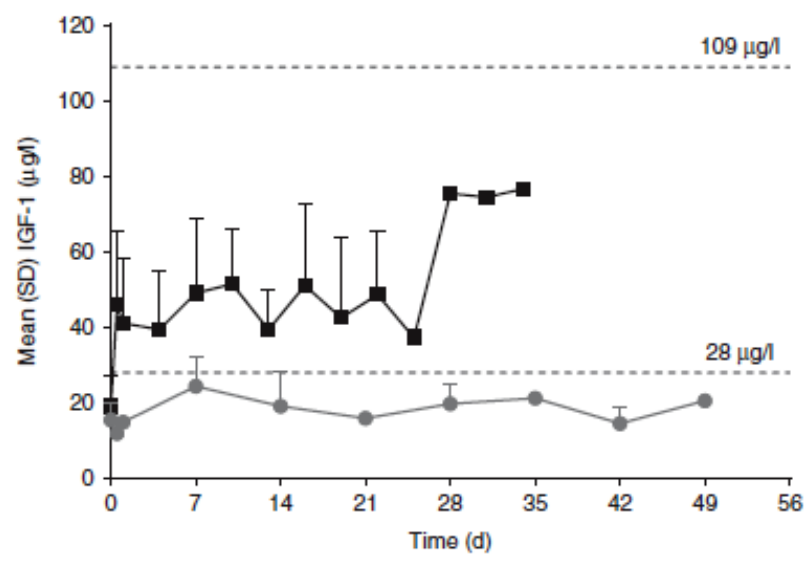

Fig. (7). Serum IGF-1 profile (mean [SD]; treated vs. control infants). Note: IGF-1 levels from treated infants on days 28,31 , and 34 were from 1 patient only, and therefore should be interpreted with caution. Closed black squares represent rhIGF-1/rhIGFBP-3 treated infants $(n=10)$. Closed grey circles represent control infants $(\mathrm{n}=9)$. Copyright $(\mathrm{CPediatric}$ Research, reproduced with permission.

\section{DISCUSSION}

We have performed a meticulous step-wise development of a dosing strategy to achieve serum IGF-1 concentrations within a target range corresponding to normal fetal levels as derived from published scientific papers on intrauterine IGF-1 concentrations. The developed dosing strategy was a result of population pharmacokinetic modeling based on prior clinical trials and on dose simulations. Finally the predicted dose regimen was verified in a clinical trial.

Further clinical trials will evaluate clinical efficacy in preventing preterm morbidities as well as short and long-term safety.

In preterm infants, the drug had to be given as an IV infusion instead of SC injection, as preterm infants have a lack of subcutaneous tissue. When giving an IV infusion we found different pharmacokinetics than earlier described with shorter half-life of IGF-I, which was the responsible factor for the administration of a continuous IV infusion.

Most medications for adults are licensed for use for certain indications, in doses and routes of administration after rigorous testing of pharmacokinetics, dosage, safety and efficacy in clinical trials. Unfortunately, few medications routinely given to very preterm infants have undergone similar evaluation. In a study of term and preterm infants in a neonatal intensive care unit during 13 weeks, as much as $54.7 \%$ of prescription episodes were off label, $9.9 \%$ were unlicensed and only $35.4 \%$ were licensed [35].

New legislation governing the development and authorization of medicines for use in infants and children entered into force in the European Union on 26 January 2007. The purpose is to ensure high-quality research for the development of medicines for children, that the majority of medicines used by infants and children are specifically authorized for such use and to ensure the availability of high-quality information about medications used.

We hope that our work will help to establish a new standard for the testing of medications for preterm infants.

\section{CONSENT FOR PUBLICATION}

Not applicable.

\section{CONFLICT OF INTEREST}

The prevention of ROP by administering IGF-I is covered by patent owned by or licensed to Premacure AB, Uppsala, Sweden. AH, DL, CL, IHP, JB and ALH own shares in a company with financial interest in Premacure AB. AH, DL, IHP, BH and LEHS work as consultants for Shire pharmaceuticals. All funding for the review is stated in acknowledgement.

\section{ACKNOWLEDGEMENTS}

This work was supported by European Commission FP7 project 305485 PREVENT-ROP (all authors)

\section{REFERENCES}

[1] Hwa VFP, Derr MA, Fiegerlova E, Rosenfeld RG. IGF-I in Human Growth: Lessons from Defects in the GH-IGF-I Axis. In: Gillman MWG, P.D. Rosenfeld, R.G., editor. Recent Advances in Growth Research: Nutritional, Molecular and Endocrine Perspectives 71. Basel: Karger AG 2013. p. 57-63.

[2] D'Ercole AJ, Ye P. Expanding the mind: insulin-like growth factor I and brain development. Endocrinology 2008; 149(12): 5958-62.

[3] Hellstrom A, Ley D, Hansen-Pupp I, et al. Insulin-like growth factor 1 has multisystem effects on foetal and preterm infant development. Acta Paediatr 2016; 105(6): 576-86.

[4] LeRoith D, Yakar S. Mechanisms of disease: metabolic effects of growth hormone and insulin-like growth factor 1. Nat Clin Pract Endocrinol Metab 2007; 3(3): 302-10.

[5] Hellstrom A, Engstrom E, Hard AL, et al. Postnatal serum insulinlike growth factor I deficiency is associated with retinopathy of prematurity and other complications of premature birth. Pediatrics 2003; 112(5): 1016-20.

[6] Fryklund L GP, Skottner A, inventorTreatment of catabolic states using authentic IGF-I and hypocaloric amount of nutrients. United States Patent no 6,034,0592000.

[7] Vanhaesebrouck S, Daniels H, Moons L, Vanhole C, Carmeliet P, De Zegher F. Oxygen-induced retinopathy in mice: amplification by neonatal IGF-I deficit and attenuation by IGF-I administration. Pediatr Res 2009; 65(3): 307-10.

[8] Han VK, D'Ercole AJ, Lund PK. Cellular localization of somatomedin (insulin-like growth factor) messenger RNA in the human fetus. Science 1987; 236(4798): 193-7.

[9] Hawkes CP, Grimberg A. Insulin-Like Growth Factor-I is a Marker for the Nutritional State. Pediatr Endocrinol Rev 2015; 13(2): 499511.

[10] Frystyk J, Hussain M, Skjaerbaek C, Porksen N, Froesch ER, Orskov $\mathrm{H}$. The pharmacokinetics of free insulin-like growth factor-I in healthy subjects. Growth Horm IGF Res 1999; 9(2): 150-6.

[11] Mizuno N, Kato Y, Iwamoto M, et al. Kinetic analysis of the disposition of insulin-like growth factor 1 in healthy volunteers. Pharm Res 2001; 18(8): 1203-9.

[12] Lofqvist C, Chen J, Connor KM, et al. IGFBP3 suppresses retinopathy through suppression of oxygen-induced vessel loss and promotion of vascular regrowth. Proc Natl Acad Sci U S A 2007; 104(25): 10589-94. 
[13] Bona G, Aquili C, Ravanini P, et al. Growth hormone, insulin-like growth factor-I and somatostatin in human fetus, newborn, mother plasma and amniotic fluid. Panminerva Med 1994; 36(1): 5-12.

[14] Kadakia R, Ma M, Josefson JL. Neonatal Adiposity Increases with Rising Cord Blood IGF-1 Levels. Clin Endocrinol (Oxf) 2016.

[15] Hansen-Pupp I, Lofqvist C, Polberger S, et al. Influence of insulinlike growth factor I and nutrition during phases of postnatal growth in very preterm infants. Pediatr Res 2011; 69(5 Pt 1): 448-53.

[16] Hansen-Pupp I, Hovel H, Hellstrom A, et al. Postnatal decrease in circulating insulin-like growth factor-I and low brain volumes in very preterm infants. J Clin Endocrinol Metab 2011; 96(4): 112935 .

[17] Hansen-Pupp I, Hovel H, Lofqvist C, et al. Circulatory insulin-like growth factor-I and brain volumes in relation to neurodevelopmental outcome in very preterm infants. Pediatr Res 2013; 74(5): 564-9.

[18] Hard AL, Smith LE, Hellstrom A. Nutrition, insulin-like growth factor-1 and retinopathy of prematurity. Semin Fetal Neonatal Med 2013.

[19] Aberg ND, Johansson UE, Aberg MA, et al. Peripheral infusion of insulin-like growth factor-I increases the number of newborn oligodendrocytes in the cerebral cortex of adult hypophysectomized rats. Endocrinology 2007; 148(8): 3765-72.

[20] Hellstrom A, Ley D, Hansen-Pupp I, et al. IGF-I in the clinics: Use in retinopathy of prematurity. Growth Horm IGF Res 2016; 30-31: 75-80.

[21] de Kerdanet M, Caron-Debarle M, Nivot S, et al. Ten-year improvement of insulin resistance and growth with recombinant human insulin-like growth factor 1 in a patient with insulin receptor mutations resulting in leprechaunism. Diabetes Metab 2015; 41(4): 331-7.

[22] Williams RM, McDonald A, O'Savage M, Dunger DB. Mecasermin rinfabate: rhIGF-I/rhIGFBP-3 complex: iPLEX. Expert Opin Drug Metab Toxicol 2008; 4(3): 311-24.

[23] Heatwole CR, Eichinger KJ, Friedman DI, et al. Open-label trial of recombinant human insulin-like growth factor $1 /$ recombinant human insulin-like growth factor binding protein 3 in myotonic dystrophy type 1 . Arch Neurol 2011; 68(1): 37-44.

[24] Hansen-Pupp I, Engstrom E, Niklasson A, et al. Fresh-frozen plasma as a source of exogenous insulin-like growth factor-I in the extremely preterm infant. J Clin Endocrinol Metab 2009; 94(2): 477-82.

[25] Hansen-Pupp I, Hellstrom-Westas L, Cilio CM, Andersson S, Fellman V, Ley D. Inflammation at birth and the insulin-like growth factor system in very preterm infants. Acta Paediatr 2007; 96(6): 830-6.

[26] Giudice LC, de Zegher F, Gargosky SE, et al. Insulin-like growth factors and their binding proteins in the term and preterm human fetus and neonate with normal and extremes of intrauterine growth. J Clin Endocrinol Metab 1995; 80(5): 1548-55.

[27] Langford K, Nicolaides K, Miell JP. Maternal and fetal insulin-like growth factors and their binding proteins in the second and third trimesters of human pregnancy. Hum Reprod 1998; 13(5): 1389-93.

[28] Lofqvist C, Niklasson A, Engstrom E, et al. A pharmacokinetic and dosing study of intravenous insulin-like growth factor-I and IGFbinding protein-3 complex to preterm infants. Pediatr Res 2009; 65(5): 574-9.

[29] Lewitt MS, Scott FP, Clarke NM, Baxter RC. Developmental regulation of circulating insulin-like growth factor-binding proteins in normal pregnancies and in pre-eclampsia. Prog Growth Factor Res 1995; 6(2-4): 475-80.

[30] Camacho-Hubner C, Rose S, Preece MA, et al. Pharmacokinetic studies of recombinant human insulin-like growth factor I (rhIGFI)/rhIGF-binding protein-3 complex administered to patients with growth hormone insensitivity syndrome. J Clin Endocrinol Metab 2006; 91(4): 1246-53.

[31] Ley D, Hansen-Pupp I, Niklasson A, et al. Longitudinal infusion of a complex of insulin-like growth factor-I and IGF-binding protein-3 in five preterm infants: pharmacokinetics and short-term safety. Pediatr Res 2012.

[32] Chung JK, Hallberg B, Hansen-Pupp I, et al. Development and verification of a pharmacokinetic model to optimize physiologic replacement of rhIGF-1/rhIGFBP-3 in preterm infants. Pediatr Res 2017.

[33] Lassarre C, Hardouin S, Daffos F, Forestier F, Frankenne F, Binoux M. Serum insulin-like growth factors and insulin-like growth factor binding proteins in the human fetus. Relationships with growth in normal subjects and in subjects with intrauterine growth retardation. Pediatr Res 1991; 29(3): 219-25.

[34] Bang P, Westgren M, Schwander J, Blum WF, Rosenfeld RG, Stangenberg M. Ontogeny of insulin-like growth factor-binding protein-1, -2 , and -3 : quantitative measurements by radioimmunoassay in human fetal serum. Pediatr Res 1994; 36(4): 528-36.

[35] Conroy S, McIntyre J, Choonara I. Unlicensed and off label drug use in neonates. Arch Dis Child Fetal Neonatal Ed 1999; 80(2): F142-4; discussion F4-5. 